\title{
ESTIMASI LAJU PERKAWINAN SILANG PADA Toona sinensis Roem DENGAN PENANDA RAPD (Random Amplified Piolymorphic DNA)
}

\section{(Out Crossing Value Estimation in Toona sinensis Roem Based on RAPD Markers)}

\author{
Jayusman $^{1 \text { \& } 3}$, Muhammad Na'iem ${ }^{2}$, Sapto Indrioko ${ }^{2}$, Eko Bhakti Hardianto ${ }^{2}$ \& \\ ILG Nurcahyaningsih ${ }^{3}$ \\ ${ }^{1}$ Mahasiswa, Universitas Gadjah Mada, Yogyakarta, Indonesia \\ ${ }^{2}$ Fakultas Kehutanan, Universitas Gadjah Mada, Yogyakarta, Indonesia \\ ${ }^{3}$ Balai Besar Penelitian dan Pengembangan Bioteknologi dan Pemuliaan Tanaman Hutan \\ Jl. Palagan Tentara Pelajar KM.15, Purwobinangun, Pakem, Sleman, Yogyakarta \\ Email: yusblora2003@yahoo.com
}

\begin{abstract}
Toona sinensis Roem or surian, belongs to the family Meliaceae. It is very important Indonesia community forest tree species because of it excellent wood quality and medicinal properties. The study investigated the mating system of T. sinensis. T. sinensis base on 88 polymorphic band Random Amplified Polymorphic DNA (RAPD) of 200 tree sample. Origin of geographical location and materials used in this research from Enrekang seed stand identified population, South Sulawesi Province. The mating parameter estimated using the mix mating model showed that this population practice a mixture of mating model with multilocus outcrossing rate $\left(t_{m}\right)$ was 0.938 , meaning that the total of outcrossing that can be among relative individual or not. The singlelocus outcrossing rate $\left(t_{s}\right)$ was 0.765 , meaning that most outcrossing occurred among non-relative tree than among relative ones $\left(t_{m^{-}} t_{m}\right)=0,172$. Highest value was obtained for correlation of selfing among families (0.999 \pm 0.045$)$, but low value obtained for correlation paternity multilocus $(0.076 \pm 0.016)$ and correlation paternity singlelocus $(-0.002 \pm 0.062)$. Maternal inbreeding coefficient $\left(F_{m}\right)$ was0.032, meaning high category. From inbreed crossing 0,062 $\left(s=1-t_{m}\right)$ was because selfing. Therefore we can concluded that $\mathrm{T}$. sinensis is low tolerance of selfing. These result have important implication to establish strategies of genetic breeding strategic of surian.
\end{abstract}

Keywords: Mating System, Out-crossing, Random Amplified Polymorphic DNA, Selfing, Toona sinensis

\begin{abstract}
ABSTRAK
Toona sinensis Roem atau surian, termasuk keluarga Meliaceae. Spesies hutan rakyat yang sangat penting di Indonesia karena memiliki kualitas kayu dan memiliki banyak manfaat sebagai obat. Penelitian ini bertujuan untuk mengetahui sistem perkawinan berdasarkan 88 pita polimorfik Random Amplified Polymorphic DNA (RAPD) dari 200 sampel pohon. Bahan yang digunakan dalam penelitian ini adalah sampel tanaman dari populasi tegakan benih teridentifikasi T. sinensis Enrekang, Provinsi Sulawesi Selatan. Estimasi parameter mating sistem menggunakan model kawin campuran menunjukan bahwa populasi ini mempraktekan model kawin campuran dengan nilai outcrossing (tm) 0,938, yang berarti bahwa total perkawinan silang pada banyak lokus dapat terjadi diantara individu berkerabat atau tidak berkerabat. Tingkat outcrossing lokus tunggal (ts) 0,765 yang berarti bahwa hubungan yang paling jauh terjadi diantara pohon tidak berkerabat daripada yang relatif $(\mathrm{tm}-\mathrm{tm})=0,172$. Nilai tertinggi ditunjukkan pada korelasi selfing antar keluarga $(0,999 \pm 0,045)$ dan koefisien kawin kerabat $(\mathrm{Fm}) 0,332$. Sedangkan nilai rendah ditunjukkan korelasi paternal multilokus $(0,076 \pm 0,016)$, korelasi lokus tunggal $(-0.002 \pm 0.062)$. Nilai selfing $(\mathrm{s}=1-\mathrm{tm})$ 0,062. Oleh karena itu dapat disimpulkan bahwa $T$. sinensis memiliki sifat toleransi rendah terhadap selfing. Hasil ini memiliki implikasi penting untuk menetapkan strategi pemuliaan genetik $T$. sinensis pada tahap lanjut.
\end{abstract}

Kata kunci: Mating Sistem, Out-crossing, Random Amplified Polymorphic DNA, Selfing dan Toona sinensis 


\section{PENDAHULUAN}

Sistem perkawinan memainkan peran penting terhadap komposisi genetik populasi, karena menentukan frekuensi genotype individu dalam beberapa generasi, dengan pengaruh yang besar terhadap pola distribusi dan besarnya variasi genetik intra dan interpopulasi (Brown, 1989). Pola perkawinan tergantung pada proses reproduksi dan struktur spasial suatu spesies. Pemahaman proses dasar reproduksi biologi serta proses kombinasi yang terjadi dapat digunakan untuk mengamati pola aliran gen dan variasi genetik (Muchugi, A. Muluvi, G. M., Simon, A. J, Wachira, F. N \& Jamnadass, 2008).

Selain itu, pengetahuan tentang sistem perkawinan spesies atau populasi juga sangat penting dan diperlukan untuk mendukung program pemuliaan tanaman. Hal ini berkaitan dengan metode pemuliaan yang akan diberlakukan pada tanaman menyerbuk sendiri akan berbeda dengan tanaman yang menyerbuk silang maupun tanaman yang memiliki sistem perkawinan campuran (Ferreira, Vencovsky, Vieira, \& Queiróz, 2000).

Studi tentang sistem perkawinan dapat digunakan untuk mengetahui laju perkawinan silang, laju perkawinan sendiri, perkawinan kerabat, biparental crossing dan beberapa parameter lainnnya. Penelitian tentang sistem perkawinan diharapkan lebih efektif dengan menggunakan penanda genetik, terutama penanda molekuler seperti Random Amplified Polymorphic DNA atau RAPD (Wadt \& Kageyama, 2004), Amplified Fragmen Lenght Polymorphic atau AFLP (Muluvi, G.M., Sprent, J.I., Odee, D., \& Powell, 2004) dan Microsatelittes (Rao, Patterson, Potts, \& R Vaillancourt, 2008). Penanda molekuler dapat dimanfaatkan untuk studi sistem perkawinan melalui estimasi rerata silang luar berdasarkan model perkawinan campuran (mixed mating model). Nilai rerata silang luar berkisar dari $\mathrm{t}=0$ (total berkawin sendiri/selfing) sampai dengan $\mathrm{t}=1$ (outcrossing), jika nilai $\mathrm{t}$ kurang dari 1 maka terjadi inbreeding yang bisa disebabkan kawin sendiri (selfing) atau pekawinan antar individu yang saling berkerabat (effective selfing).

Sistem perkawinan suatu jenis tanaman bersifat dinamis, beragam dari suatu tempat ke tempat lain maupun dari waktu ke waktu. Sistem perkawinan sangat dipengaruhi oleh faktor lingkungan dan genetik (Finkeldey, R., \& Hattemer, 2007). Spesies pada sebaran alami yang memiliki ukuran populasi sempit sering diasumsikan mampu beradaptasi terhadap potensi afek yang merugikan terhadap ukuran populasi yang menyebabkan terfragmentasinya kelangsungan populasi, namun demikian tetap terjadi gangguan terhadap pola aliran yang menyebabkan perubahan pada aliran gen dan pola perkawinan dalam populasi. Studi pola perkawinan pada populasi kecil cukup penting dilakukan seperti pada populasi tegakan benih. Hasil pengamatan pengaruh kerapatan populasi pada hutan alam, hutan sekunder dan kebun benih menunjukkan laju outcrossing menurun (Lee, 2000). Sampai saat ini informasi laju outcrossing spesies $T$. sinensis belum tersedia sehingga cukup penting untuk evaluasi. Tujuan utama dari penelitian ini adalah untuk mengkaji mekanisme pola perkawinan populasi tegakan benih teridentifikasi $T$. sinensis berdasarkan penanda molekuler RAPD.

\section{BAHAN DAN METODE}

\section{Koleksi Sampel}

Sebanyak 200 individu tanaman $T$. sinensis yang mewakili populasi Enrekang sudah ditanam pada plot uji keturunan 
dianalisis menggunakan 10-primer terseleksi hasil penelitian sebelumnya. Populasi tersebut ditetapkan untuk mewakili tegakan benih terindetifikasi $T$. sinensis Enrekang, Sulawesi Selatan. Deskripsi lokasi asal populasi tertera di Gambar 1 .

\section{Isolasi DNA}

Genom DNA dari 96 individu tanaman diekstraksi dari 50-60 gr daun kering $T$. sinensis dengan metode CTAB (Cetyl Trimethyl Ammonioum Bromide) yang telah dimodifikasi (Shiraishi \& Watanabe,1995).

\section{Purifikasi DNA}

Purifikasi DNA dilakukan dengan menggunakan Gene Clean III Kit. Prinsip utama metoda ini adalah berdasarkan penggunaan silica (glassmilk). Hasil ektraksi kemudian di sentrifus dengan penambahan $25 \mathrm{ul} \mathrm{psdH}_{2} \mathrm{O}$. Setelah divortex lalu ditambahkan 300 ul NAI (3 x volume larutan DNA $+\operatorname{psdH}_{2} \mathrm{O}$ ).

\begin{tabular}{|c|c|c|}
\hline & Deskripsi & $\begin{array}{l}\text { Kabupaten Enrekang } \\
\text { (Sulawesi Selatan) }\end{array}$ \\
\hline & Latitude & $03^{\circ} 21^{\prime} 023^{\prime \prime}(\mathrm{LS})$ \\
\hline & Longitude & $119^{\circ} 03^{\prime} 020^{\prime \prime}(\mathrm{BT})$ \\
\hline & Altitude & $665 \mathrm{~m} \mathrm{dpl}$ \\
\hline & Curah Hujan (mm/thn) & $2350-2450$ \\
\hline & Temperatur (min-max) & $22^{\circ} \mathrm{C}-29^{\circ} \mathrm{C}$ \\
\hline & MusimKemarau & Mei-September \\
\hline & Topography & $\begin{array}{l}\text { Bergelombang-berbukit } \\
\text { (kelerengan } 3-15 \% \text { ) }\end{array}$ \\
\hline 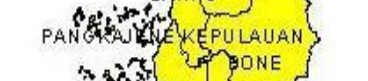 & Tanah & Podsolik merah dan coklat \\
\hline & Tipe Hutan & Hutan rakyat (diskontinyu) \\
\hline 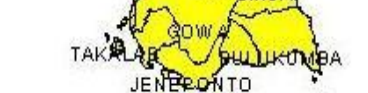 & Status & Tegakan Benih Teridentifikasi \\
\hline
\end{tabular}

Gambar 1. Peta tegakan benih terindentifikasi T. Sinensis Enrekang - Sulawesi Selatan asal 200 sampel Toona sinensis Roem

Figure 1. Map of seed stands identified T. sinensis Enrekang - South Sulawesi from 200 samples Toona sinensis Roem

Pelet hasil purifikasi dikeringkan dengan desiccator lalu ditambah $\mathrm{psdH}_{2} \mathrm{O}$ kemudian divortex ulang. Sebanyak 57ul larutan DNA yang diperoleh disimpan dalam microtube berukuran $1,5 \mathrm{ml}$. 


\section{Kuantifikasi DNA}

Uji Kuantitas DNA menggunakan alat Gene Quant (Parmacia pada panjang gelombang A230, A260, A280 dan A320 nm. Prinsip alat Gene Quant adalah menghitung rasio dan konsentrasi DNA dengan memanfaatkan optical density (OD) pada absorbansi beberapa panjang gelombang cahaya. Panjang gelombang $260 \mathrm{~nm}$ merupakan panjang gelombang yang dapat diserap DNA secara maksimal, sedangkan panjang gelombang 280 merupakan panjang gelombang yang dapat diserap RNA secara maksimal. Rasio DNA/RNA yang paling baik adalah 1,8 2,2 .

\section{Dilusi}

Dilusi adalah pengenceran DNA untuk mempermudah penggunaan konsentrasi larutan DNA yang sudah dikuantifikasi. Dilusi volume hasil purifikasi dilakukan berdasarkan konsentrasi hasil kuantifikasi dengan penambahan $\mathrm{psdH}_{2} \mathrm{O}$ sesuai dengan konsentrasi DNA.

\section{PCR amplification}

Amplifikasi PCR dilakukan dengan mesin Thermal Cycler Gene Amp PCR System 9700 Applied Biosystem dengan total volume 10 ul per sampel. Bahan reaksi PCR terdiri dari $1 \mathrm{x}$ buffer $(10 \mathrm{mM}$ Tris-HCL pH 8,3, $10 \mathrm{mM}$ KCL, 3,0 mM $\mathrm{MgCl}_{2}$ ), $200 \mu \mathrm{M}$ tiap dNTPSs, 0,25 $\mu \mathrm{M}$ primer, 0,5 unit/10 $\mu 1$ amplitaq DNA polymerase (Stoffel Fragment, Applied Biosystem) dan $10 \mathrm{ng}$ larutan DNA.

Proses PCR diawali dengan denaturasi selama 120 detik ada suhu $94^{\circ} \mathrm{C}$, diikuti dengan 45 siklus yang masingmasing terdiri dari denaturasi selama 30 detik pada suhu $94^{\circ} \mathrm{C}$, annealing (penempelan primer) selama 30 detik pada suhu $37^{\circ} \mathrm{C}$, extension (pemanjangan) selama 90 detik pada suhu $72^{\circ} \mathrm{C}$. Proses PCR diakhiri dengan pemanjangan selama 7 menit pada suhu $72^{\circ} \mathrm{C}$. Hasil aplifikasi PCR dielektroforesis pada $1,5 \%$ gel agarose dalam buffer TBE (Tris Borac EDTA) yang ditambahkan ethidium bromide (Sambrook, Fritsch, \& Maniatis, 1989), 20 x Tris Borac EDTA buffer dan $0,5 \%$ ethidium bromide selama \pm 2 jam pada tegangan 120 Volt. Hasil elektroforesis tersebut selanjutnya didokumentasikan menggunakan Fotodyne Analyser.

\section{RAPD profiling}

Pada penelitian ini, terdapat primer yang memproduksi pita polymorfis terbanyak yaitu OPB-03 (12 DNA bands), OPB-10 (12 DNA bands) DANOPY-11 (11 DNA bands) dan yang terendah menghasilkan pita polimorfis yaitu OPY-08 (3 DNA bands) dan OPY-11 (5DNA bands). Persentase pita polymorfis yang dihasilkan rata-rata $84,875 \%$. Profil pita RAPD T. sinensis tertera pada Tabel 1 dan Gambar 2.

\section{Analisis Data}

Analisis mating sistem berdasarkan multilocus mixed program (MLTR) (Ritland K, 1983, 1990, 2002). Berdasarkan data tegakan benih teridentifikasi, dilakukan estimasi berdasarkan program MLTR, yang secara simultan menghitung laju perkawinan silang multilokus (tm), laju perkawinan silang lokus tunggal (ts), perkawinan sendiri (1-tm), perkawinan kerabat (tm-ts); koefisien kawin kerabat $(\mathrm{F})$; korelasi antar tetua (rp), dan korelasi perkawinan sendiri antar famili (rs). Estimasi dihitung 
menggunakan metode maximum like lihood, numerical algorithm expectation maximization (EM) dan varians kuantitas menggunakan metode boostrap dimana data keturunan (dalam famili) setiap unit menggunakan satuan ulang sampling 1000 bootstraps.

Tabel 1.Jumlah pita RAPD, ukuran pita, dan jumlah pita polimrfis dari setiap primer yang digunakan

Table 1. The number of RAPD bands, size of the tape, and number of polymorphic bands of each primary used

\begin{tabular}{|c|c|c|c|c|c|c|}
\hline Primer & $\begin{array}{l}\text { Sequens } \\
\left(5^{\prime}-3^{\prime}\right)\end{array}$ & $\begin{array}{c}\text { G+C } \\
\text { Komposisi } \\
(\%)\end{array}$ & $\begin{array}{c}\text { Jumlah } \\
\text { Fragment }\end{array}$ & $\begin{array}{l}\text { Fragment } \\
\text { Polimorfis }\end{array}$ & $\begin{array}{c}\text { Persentase } \\
(\%)\end{array}$ & $\begin{array}{c}\text { Ukuran Fragment } \\
\text { (Base Pair/bp) }\end{array}$ \\
\hline OPB-03 & CATCCCCCTG & 70 & 15 & 12 & 80 & $\begin{array}{l}200,250,290,310, \\
360,450,500,550, \\
600,650,750,800, \\
880,910,110\end{array}$ \\
\hline OPB-04 & GGACTGGAGT & 60 & 11 & 9 & 82 & $\begin{array}{l}150,300,350,400 \\
425,480,500,600 \\
650,750,900\end{array}$ \\
\hline OPB-10 & CTGCTGGGAC & 70 & 13 & 12 & 292 & $\begin{array}{l}220,250,300,330, \\
410,480,500,510, \\
580,620,780,810, \\
830\end{array}$ \\
\hline OPY-06 & AAGGCT CACC & 60 & 10 & 9 & 90 & $\begin{array}{l}210,290,410,510, \\
580,650,700,780, \\
800,900\end{array}$ \\
\hline OPY-07 & AGAGC CGTCA & 60 & 11 & 9 & 82 & $\begin{array}{l}320,380,410,490 \\
510,580,600,680, \\
800,900,1100\end{array}$ \\
\hline OPY-08 & AGGCAGAGCA & 60 & 4 & 3 & 75 & $220,350,420,480$ \\
\hline OPY-10 & CAAACGTGGG & 60 & 13 & 11 & 85 & $\begin{array}{l}210,250,300,330, \\
380,400,450,490, \\
500,580,680,700, \\
810\end{array}$ \\
\hline OPY-11 & AGACGATGGG & 60 & 6 & 5 & 83 & $\begin{array}{l}350,410,480,500 \\
600,690\end{array}$ \\
\hline OPY-14 & GGTCGATCTG & 60 & 11 & 8 & 91 & $\begin{array}{l}210,280,300,390 \\
400,480,500,520 \\
550,600,700\end{array}$ \\
\hline OPO-06 & CCACGGGAAG & 70 & 9 & 8 & 89 & $\begin{array}{l}200,220,310,370 \\
450,500,580,690 \\
900\end{array}$ \\
\hline
\end{tabular}




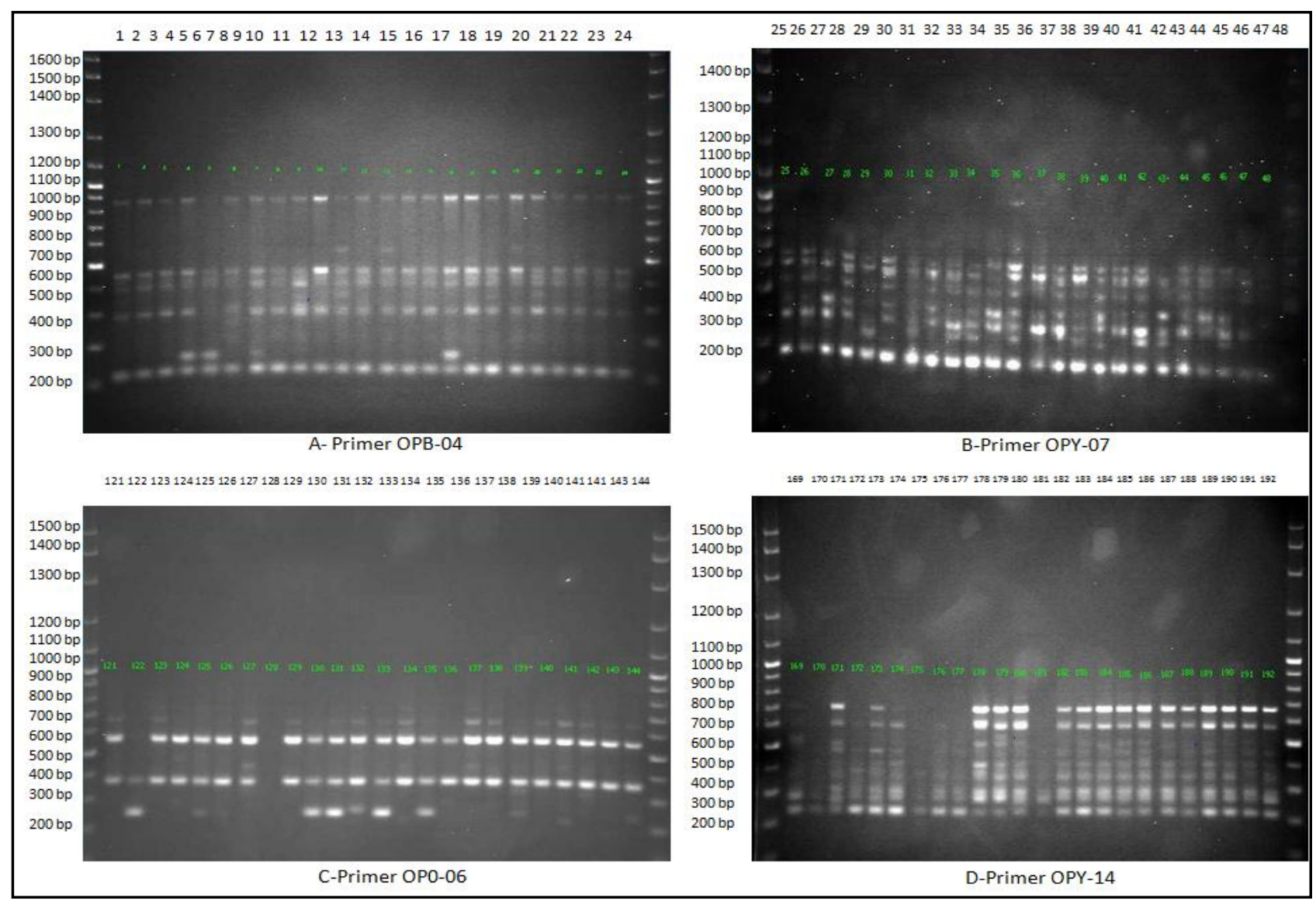

Gambar 2. Profil RAPD (A) primer OPB-04, nomor genotipe 1-24, (B) primer OPY 07, nomor genotipe 25-48, (C) primer OPO-06, nomor genotipe121-144 and (D) primer OPY-14, nomor genotipe169-192

Figure 2. RAPD profile (A) primary OPB-04, genotype 1-24, (B) primary OPY 07, genotype number 25-48, (C) primary OPO-06, genotype121-144 and $(D)$ primer OPY-14, genotype 169-192 number

\section{HASIL DAN PEMBAHASAN}

\section{A. Hasil}

Sebanyak 103 pita fragmen DNA yang dihasilkan dari 10 primer terseleksi terdapat 88 pita yang polimorfik $(84,87 \%)$ dan selanjutnya digunakan dalam analisis data sistem perkawinan Toona sinensis Roem. Estimasi awal terhadap sistem perkawinan pada Toona sinensis berdasarkan populasi dari Enrekang, Sulawesi Selatan yang telah ditetapkan sebagai tegakan benih terindentifikasi dan berdekatan dengan hutan rakyat dengan distribusi cukup luas serta adanya serangga penyerbuk. Hasil estimasi terhadap parameter sistem perkawinan tertera pada Tabel 2.

Tabel 2 menunjukkan bahwa $T$. sinensis memiliki model perkawinan campuran dengan nilai laju perkawinan silang multilokus $\left(\mathrm{t}_{\mathrm{m}}\right) 0,938$ atau sebesar $93,8 \%$, nilai laju perkawinan lokus tunggal (ts) sebesar 0,765 , perkawinan sendiri atau selfing $(\mathrm{s}=1$ tm) sebesar 0,062 dan kawin kerabat (tm-ts) sebesar 0,172. Koefisien perkawinan kerabat sebesar 0,038 atau 3,8\%, nilai korelasi paternal (rp) sebesar 0,076 dan korelasi selfing (rs) sebesar 0,999 . 
Tabel 2.Estimasi parameter sistem perkawinan pada populasi $T$. sinensis yang dihasilkan penanda RAPD menggunakan metode maximum likelihood dan standard galat dihitung berdasarkan 1000 bootstraps

Table 2. Estimation of marine system parameters in $T$. sinensis population generated RAPD marker using maximum likelihood method and error standard calculated on 1000 bootstraps

\begin{tabular}{|c|c|c|}
\hline Parameter & Estimasi & Persentase (\%) \\
\hline $\begin{array}{l}\text { Nilai rata-rata kawin silang yang diamati pada banyak } \\
\text { lokus(Multilocus out-croosing rate }\left(t_{m}\right)\end{array}$ & $0,938( \pm 0,024)$ & 93,8 \\
\hline $\begin{array}{l}\text { Nilai rata-rata kawin silang yang diamati pada suatu } \\
\text { lokus(Singlelocus out-croosing rate }\left(t_{s}\right)\end{array}$ & $0,765( \pm 0,017)$ & 76,5 \\
\hline Nilai rata-rata perkawinan sendiri (Selfing $\left(1-t_{m=} s\right)$ & $0,061( \pm 0,0764)$ & 6,1 \\
\hline Peluang terjadinya perkawinan kerabat & $0,172( \pm 0,022)$ & 17,2 \\
\hline \multicolumn{3}{|l|}{ Biparental inbreeding $\left(t_{m}-t_{s}\right)$} \\
\hline $\begin{array}{l}\text { Koefisien perkawinan kerabat pada induk betina yang } \\
\text { diamati pada lokus tunggal }\end{array}$ & $0,332( \pm 0,039)$ & 33,2 \\
\hline \multicolumn{3}{|l|}{ (Maternal inbreeding coefficients $\left(\mathrm{F}_{\mathrm{m}}\right)$} \\
\hline $\begin{array}{l}\text { Proporsi keturunan yang berasal dari induk betina dan } \\
\text { jantan yang sama pada banyak lokus (Multilocus } \\
\text { Correlation of paternity }\left(r_{p(m)}\right)\end{array}$ & $0,076( \pm 0,016)$ & 7,6 \\
\hline $\begin{array}{l}\text { Proporsi keturunan yang berasal dari induk betina dan } \\
\text { jantan yang sama pada lokus tunggal }\end{array}$ & $-0,002( \pm 0,062)$ & $-0,2$ \\
\hline \multicolumn{3}{|l|}{ (singlelocus Correlation of paternity $\left(r_{p(s)}\right)$} \\
\hline $\begin{array}{l}\text { Proporsi keturunan yang berasal dari induk betina dan } \\
\text { jantan yang sama (Correlation of paternity }\left(r_{p(m)}\right)-\left(r_{p(s)}\right)\end{array}$ & $-0,079( \pm 0,066)$ & $-7,9$ \\
\hline $\begin{array}{l}\text { Nilai korelasi selfing antar lokus } \\
\text { (Correlation of selfing }\left(r_{s}\right)\end{array}$ & $0,999( \pm 0.045)$ & 78 \\
\hline
\end{tabular}

\section{B. Pembahasan}

Nilai estimasi laju perkawinan silang sering menghasilkan perbedaan terutama pada famili dan populasi yang memiliki polinator serangga, sebagaimana dilaporkan (Vogler \& Kalisz, 2001) bahwa sebanyak $49 \%$ spesies tersebut menunjukkan perkawinan silang pada kisaran 20\% - 80\%. Estimasi sistem perkawinan $T$. sinensis secara dominan adalah outcrossing (93,8 \%) dengan kemungkinan terjadi selfing rendah $(6,2 \%) . T$. sinensis memiliki tipe bunga hermaprodit dengan sistem pembungaan protandri dikogami, bunga jantan dan betina dalam satu pohon (biseksual) tetapi juga bisa aseksual (Edmond, J. M. \& staniforth, 1998). Pada tumbuhan dengan bunga biseksual menghasilkan biji dari pembuahan sendiri. Tingginya nilai outcroosing pada $T$. sinensis dengan bunga biseksual tersebut didukung oleh keberadaan serangga penyerbuk dan potensi tingkat reseptivitas pembungaan tidak bersamaan. Jarak antar pohon induk yang berjauhan memberikan peluang tanaman melakukan perkawinan silang lebih besar. Secara fisiologis serbuk sari surian masak dan segera membuka sebelum putik siap dibuahi. Pucuk kepala stilus selalu tidak 
reseptif polen. Stamen tidak menempel pada kepala stilus, korola gugur dalam jangka waktu pendek sesudah fase jantan. Kondisi tersebut memperkecil terjadinya perkawinan sendiri. Pada spesies Dyera lowii yang memiliki alat reproduksi biseksual dan bersifat protandri memiliki mekanisme self incompatibility dengan nilai outcrossing yang tinggi (Middleton, 2007; Wahyudiningsih, 2015)

Penelitian pada beberapa pohon tropis lain dengan menggunakan penanda RAPD menunjukkan adanya nilai outcroosing lebih tinggi dibanding $T$. sinensis seperti pada spesies Passiflora alata 0,994, (Ferreira et al., 2009) dan Camelia sinensis 0,988 (Muoki et al., 2007).

Nilai $\mathrm{tm}$ lebih rendah dari $T$. sinensis dengan menggunakan penanda RAPD dilaporkan pada Pinus maximinoi (0,904; (Dvorak, Hamrick, Furman, Hodge, \& P, 2002) Acacia hybrid (0,860, (Hong, Lee, KitSiong, Muhammad, \& Ratnam, 2009), Stylosanthes guianensis (0,386; (Chiari, L., Resende, R.M.S., \& Matinda, 2010) dan Eucalypthus urophylla (0,930; (Gaiotto FA, Bramucci, M. \& Grattapaglia, 1997).

Nilai $t m$ lebih tinggi dari $T$. sinensis menggunakan penanda Microsatelit atau Simpel Sequence Repeat (SSR) pada Melia azedarach $\left(t_{m}=1,00\right.$; (Azizah \& Siregar, 2011); Tabebuiaroseo alba $(0,963$; (Feres et al., 2012), Alnus maritime (0,942; (Jones, J.M and Gibson, 2012), Swietenia macrophylla (0,938; (Lemes, M.R., Grattapaglia, D., Grogan, J., Proctor, J. \& Gribel, 2007) dan Koompassia Malaccensis (0,994; (Lee, C.T, Lee, S.L, Ng, K.K.S, Faridah2, F.S, Siraj, S.S. \& Norwati, 2011).

$$
\text { Penggunaan penanda AFLP }
$$
menunjukkan nilai outcrossing yang lebih rendah dibandingkan $T$. sinensis seperti laporan (Muluvi, G.M., Sprent, J.I., Odee, D.,
\& Powell, 2004) pada Moringa oleifera dengan tm=0,75, Eucalyptus urophylla $(0,890$; (Gaiotto FA, Bramucci, M. \& Grattapaglia, 1997) dan Myracroduon urundeuva $(0,940$; (Freitas1, M.L.M, Sebbenn, A.M, Moraes, M.L.T \& Lemos, 2004).

Nilai $t_{m}$ lebih tinggi dari $t_{m} T$. sinensis dengan menggunakan penanda isozym. Nilai $t_{m}$ diantaranya dilaporkan pada Cedrus lebani (0,940: (Banu, Kurt, \& Kaya, 2012), Guaiacum sanctum (Zygophyllaceae) (0,950; (Fuchs, E.J \& Hamrick, 2011), Acer macrophyllus Pursh (0,950; (Iddrisu \& Ritland, 2004) dan Pterocarpus macrocarpus (0,959; (Liengsiri, C., Yeh, F.C, \& Boyle, 1998)) sedangkan Nilai $t_{m}$ lebih kecil dari $t_{m}$ T. sinensis dilaporkan pada Douglas fir (0,752; (Stauffer \& Adam, 1993), Carapa purcera - Meliaceae (0,780; (Agnes Doligez \& Joly, 1997), dan Dyera lowii (0,801; (Wahyudiningsih T.S, 2015).

Nilai $t m$ lebih rendah dari $t m T$. sinensis dengan menggunakan penanda ISSR (Inter-Simple Sequence Repeats) pada Camelia sinensis (0,936; Muoki et al, 2007) dan pada Nelumbo nucifera (0,900; Han et al., 2009) dan Lansium parasiticum (0,065; Murni et al., 2016).

Tingginya nilai out crossing dari famili Meliaceae dimana $T$. sinensis termasuk salah satu spesies di dalamnya ditunjukkan oleh spesies Melia azedarach (Azizah \& Siregar, 2011), Swietenia macrophilla (Lemes, M.R., Grattapaglia, D., Grogan, J., Proctor, J. \& Gribel, 2007), Carapa purcera (Agnes Doligez \& Joly, 1997) Cedrela odorata (Sanches, 2008), Carapa guinensis (de Campos, 2013) dan Azadirachta India (Kundu, 1999). Perbandingan nilai laju outcrossing dan biparenthalin breeding pada penelitian ini dengan hasil Gambar 2. 


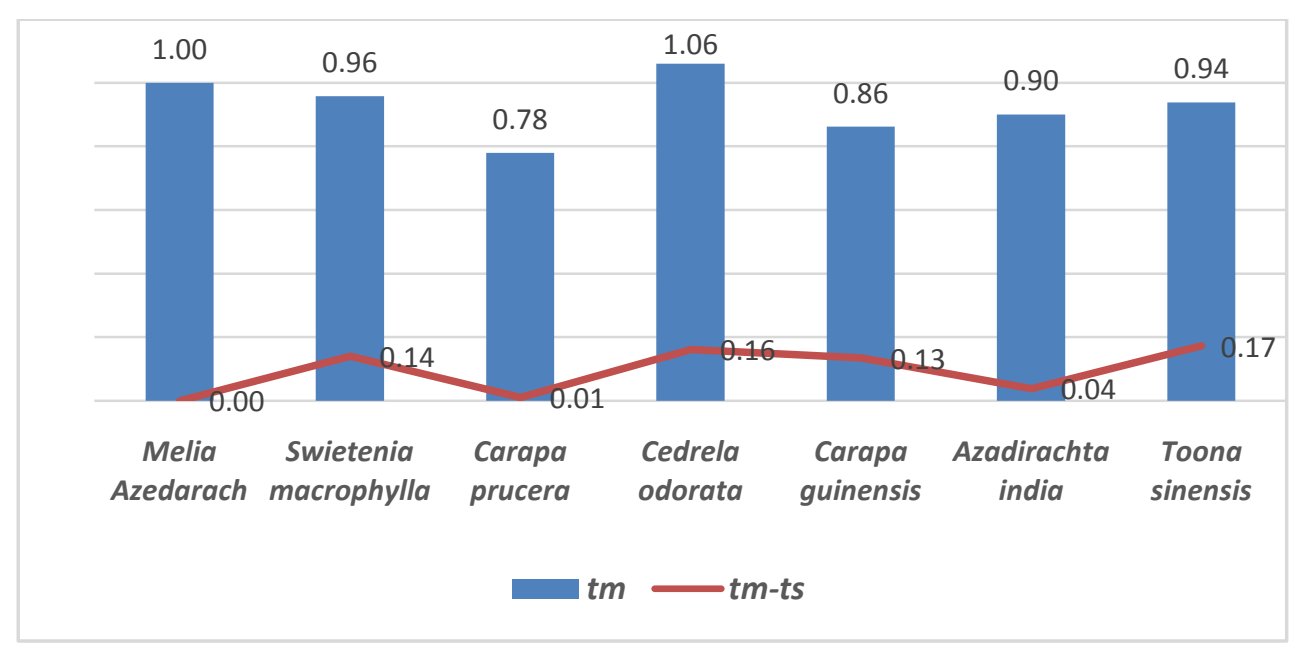

Gambar2. Perbandingan nilai outcrossing dan inbreeding pada $T$. sinensis Roem dan 6 spesies dari famili Meliaceae pada pohon tropis. Diagram batang menunjukkan nilai outcrossing dan diagram garis menunjukkan nilai inbreeding

Figure 2. Comparison of outcrossing and inbreeding values on Roem T. sinensis and 6 species from the Meliacea family to tropical trees. The bar chart shows the value of outcrossing and line chart shows the value of inbreeding

Berdasarkan Gambar 2 di atas menunjukkan bahwa beberapa spesies famili Meliaceae memiliki kecenderungan melakukan outcrossing yang cukup tinggi dan memiliki nilai laju inbreeding yang rendah dan selaras dengan hasil pada penelitian ini. Estimasi multilokus secara statistik lebih efisien daripada lokus tunggal karena kumpulan data multilokus berisi lebih banyak info tentang outcrossing daripada yang tersedia pada lokus tunggal (Muluvi, G.M., Sprent, J.I., Odee, D., \& Powell, 2004).

Analisis terhadap kerabat dekat yang menghasilkan nilai lebih tinggi kemungkinan homozigositas di beberapa lokus, sehingga estimasi nilai lokus tunggal akan dapat memberikan informasi tambahan tentang seberapa erat kaitannya dengan keturunan yang berkerabat. Untuk estimasi multilokus, semua lokus akan digunakan namun estimasi akan diperoleh secara terpisah (satu per satu), sedangkan perkiraan multilokus mempertimbangkan semua lokus pada saat bersamaan.

Variasi besarnya nilai perkawinan silang lokus tunggal yang sangat tinggi sering ditemukan pada populasi yang terisolasi, yang disebabkan oleh perkawinan antara induk berkerabat karena kesalahan sampling serta akibat jumlah keturunan setiap populasi di tingkat isolasi nilainya kurang dari 1,0. Faktor utama yang dapat menyebabkan estimasi melebihi nilai 1,0 adalah karena adanya ketidakcocokan diri (incompatibility) suatu spesies. Pada model perkawinan campuran juga terdapat ketidaksesuaian yang disebabkan karakteristik sampling dan kondisi populasi. Pendugaan terhadap distribusi frekuensi gen tidak identik dengan penyebaran serbuksari semua pohon induk karena memiliki tingkat isolasi yang berbeda yang dapat menyebabkan serbuk sari heterogen. 
Perbedaan nilai outcrossing multilokus dan lokus tunggal menunjukkan adanya biparental inbreeding atau perkawinan antar kerabat (Ritland K, 2002), besarnya biparental inbreeding di dalam populasi $T$. sinensis adalah 0,172 yang berkontribusi pada tingkat variasi genetik pada populasi tersebut. Berdasarkan perbedaan diantara estimasi laju perkawinan silang multilokus dan rerata estimasi lokus tunggal mengindikasikan bahwa fraksi perkawinan silang multilokus sebesar $17,2 \%$ terjadi diantara individu yang berkerabat.

Nilai perkawinan silang yang tinggi antar induk tanaman $(\mathrm{tm}=93,8 \% \quad \&$ $\mathrm{ts}=76,5 \%$ ) menunjukkan bahwa kemungkinan terjadinya perkawinan silang pada calon induk atau populasi sangat besar, sehingga potensi perkawinan kerabat yang terjadi sangat rendah $(17,2 \%)$. Hal ini merupakan dukungan yang baik untuk mempertahankan keragaman genetik di plot uji keturunan yang sudah dibangun dengan populasi yang diuji dalam penelitian ini. Populasi tersebut diyakini mampu menjaga kemampuan reproduksinya dalam jangka pendek serta akan mampu beradaptasi menghadapi perubahan lingkungan yang dinamis dalam jangka panjang (Frankham, R., Ballou, J.D., $\&$ Briscoe, 2002). Nilai (tm-ts) sebesar $17,2 \%$ menunjukkan bahwa masih terdapat potensi kawin kerabat (selfing dan perkawinan kerabat) pada tanaman $T$. sinensis. (Finkeldey, R., \& Hattemer, 2007) Finkeldey, (2005) menyebutkan bahwa fenomena tingginya silang dalam dipengaruhi oleh faktor genetik dan lingkungan. Faktor genetik yang mempengaruhi silang dalam antara lain struktur bunga, sistem seksual dan waktu pembungaan yang dimiliki tanaman $T$. sinensis. Sedangkan faktor lingkungan yang mempengaruhi silang dalam yaitu kurangnya polinator atau vektor penyerbuk. Peluang kawin kerabat tersebut dapat perkecil dengan pengaturan jarak tanam yang optimal untuk mendorong perkawinan silang dengan menanam pohon-pohon yang bergenotipe berbeda. Tingkat perkawinan kerabat meskipun relatif rendah masih dapat diturunkan. Salah satu langkah yang dapat ditempuh adalah menurunkan peluang terjadinya kawin kerabat dengan melakukan infusi (menambah materi genetik baru dalam populasi). Hal ini terkait jumlah famili dan sebaran asal lokasi famili yang digunakan membangun plot uji keturunan masih sangat terbatas sehingga kurang ideal.

Nilai tm-ts $T$. sinensis lebih tinggi dari dibandingkan (tm-ts) Dyera lowii (0,129; (Wahyudiningsih T.S, 2015), (tm-ts) Swietenia macrophilla (0,117; (Lemes, M.R., Grattapaglia, D., Grogan, J., Proctor, J. \& Gribel, 2007); (tm-ts) dan Warburgia ungandensis (0,023;(Muchugi, A. Muluvi, G.M., Simon, A.J, Wachira, F.N \& Jamnadass, 2008), tetapi lebih rendah dari (tm-ts) Moringa oleifera (0,260; (Muluvi, G.M., Sprent, J.I., Odee, D., \& Powell, 2004). Meskipun rendah, beberapa perkawinan silang biparental terlihat pada keduanya. Muluvi, G.M., Sprent, J.I., Odee, D., \& Powell, (2004) menjelaskan bahwa terdapat dua faktor yang dapat menyebabkan terjadinya estimasi penilaian yang terlalu tinggi pada analisis mating sistem yaitu (1) adanya ketidaksesuaian perkawinan silang dan (2) potensi penyimpangan perkawinan campuran. Cleegg (1980) menambahkan terdapat tiga asumsi penting yang berperan yaitu (1) terjadinya perkawinan silang acak atau pembuahan diri, (2) frekuensi gen distribusi di antara serbuk sari dan (3) tingkat outcrossing tidak tergantung pada genotipe induk. Analisis sistem perkawinan di tingkat 
populasi besar menunjukkan tingkat keberhasilan pada perkawinan silang multilokus dan lokus tunggal yang lebih tinggi pada famili dibandingkan pada populasi kecil.

Nilai koefisien inbreeding (F) $T$. sinensis menunjukkan nilai positif $(0,038)$. Nilai positif tersebut disebabkan seleksi yang kurang mendukung heterosigositas pada lokus yang diteliti (Finkeldey, R., \& Hattemer, 2007). Jika heterosigositas observasi tidak melebihi heterosigositas harapan sesuai hukum Hardiweinberg maka nilai $F m$ menjadi positif. (Wright S, 1965) menjelaskan bahwa terdapat sistimatika penghindaran perkawinan antar kerabat di dalam sub populasi dan cenderung lebih besar pada strain yang berbeda. Hasil perhitungan koefisien inbreeding harapan menggunakan persamaan $\quad(\mathrm{Feq}=(1-\mathrm{tm}) /(1+\mathrm{tm}) \quad$ maka diperoleh nilai 0,032 , sedangkan nilai estimasi $\mathrm{F}=0,038$. Nilai $\mathrm{F}$ observasi lebih besar dari nilai $\mathrm{F}$ harapan, sehingga populasi $T$. sinensis di tegakan benih terindentifikasi telah mencapai keseimbangan inbreeding. Koefisien inbreeding maternal $(\mathrm{F}=0,038)$ dan koefisien induk maternal harapan (Feq=0,032) termasuk kategori rendah, maka terjadi penghindaran kawin kerabat.

Nilai korelasi paternal adalah besarnya kejadian persilangan yang berasal dari individu yang berkerabat. Nilai korelasi paternal tinggi mengindikasikan bahwa persilangan terjadi pada pohon-pohon yang berdekatan. Hal ini disebabkan oleh aktivitas polinator yang cenderung mengunjungi pohon-pohon yang berdekatan pada waktu terjadi pembungaan serentak. Nilai rp pada penelitian ini untuk lokus tunggal -0,002 dan rp multilokus 0,076, jika nilai korelasi paternal $r_{p}(p)$ tunggal lebih rendah dari korelasi paternal $r_{p}(m)$ multilokus berarti persilangan antar individu berkerabat lebih tinggi. Berdasarkan nilai rp yang rendah menunjukkan bahwa persilangan antar individu berkerabat relatif rendah. Perbedaan korelasi paternal $\left(\mathrm{r}_{\mathrm{p}}(\mathrm{m})-\mathrm{r}_{\mathrm{p}}(\mathrm{p})\right)$ pada $T$. sinensis sebesar -0,079. Nilai negatif tersebut menunjukkan adanya perbedaan induk jantan yang terlibat dalam persilangan (Muchugi, A. Muluvi, G.M., Simon, A.J, Wachira, F.N \& Jamnadass, 2008).

Nilai rp sangat dipengaruhi oleh pembungaan (Nurjahjaningsih, 2010). Nilai rp rendah $(-0,079)$ pada populasi $T$. sinensis menunjukkan adanya pembungaan yang lebih seimbang yaitu bunga betina yang melimpah diimbangi bunga jantan yang juga melimpah. Sebaliknya jika nilia rp tinggi maka terjadi ketidakseimbangan pembungaan dengan bunga betina melimpah tetapi bunga jantan sedikit. Jika nilai rp tunggal dikurangi rp multi hasilnya negatif maka terjadi perbedaan induk jantan yang terlibat persilangan antar famili.

Korelasi selfing antar lokus (rs) pada T. sinensis sebesar 0,999. Nilai positif ini mengimplikasikan bahwa sampel keturunan selfing berasal dari induk yang sama. Nilai selfing tersebut tidak terikat pada lokus tertentu. Korelasi sefing antar lokus menunjukkan adanya kecenderungan famili tertentu bersilang diri.

Rendahnya variasi genetik antara pohon induk tergantung dari efisiensi aliran gen, suatu faktor yang dipengaruhi oleh penyerbukan silang yang efektif. Pada tanaman dengan perkawinan silang terdapat konsistensi terhadap tingginya keragaman genetik dan rendahnya nilai diferensiasi populasi (Lee, S.L., Wickneswari, R., Mahani, M.C., \& Zakri, 2000). Faktor lain yang menentukan suatu sistem perkawinan spesies adalah peran polinator (penyerbuk). 
Bunga $T$. sinensis mempunyai warna yang indah sehingga menjadi faktor yang menarik kedatangan serangga ke bunga tersebut. Polinator memanfaatkan polen yang ada sebagai vektor pembawa serbuk sari dari satu bunga ke bunga lainnya dalam satu pohon maupun antar pohon. Kunjungan polinator ke bunga dipengaruhi oleh warna, bau dan bentuk. Penyebaran serbuk sari oleh polinator mencapai wilayah yang luas. Kecukupan jumlah serangga polinator serta pola perilakunya juga sangat menentukan pola aliran gen di dalam populasi. Adanya sejumlah tanaman yang merupakan hasil perkawinan kerabat menunjukkan perilaku polinator yang mengunjungi bunga-bunga yang reseptif secara serempak pada individu tanaman yang sama.

Mekanisme penyerbukan pada tanaman sangat menentukan pola variasi genetik tersebut (Bawa, 1990). Pramono et al., (2016) melaporkan sebanyak 12 jenis serangga mengunjungi bunga $T$. sinensis diantaranya berasal dari famili Thripidae (Thrips) yaitu serangga bersayap kecil berukuran 0,5 - $11 \mathrm{~mm}$ dan famili Nitidulidae yaitu kumbang. Hidayat (2010) menambahkan bahwa kumbang, lebah dan lalat sebagai serangga yang berperan sebagai penyerbuk sedangkan Thrips dan serangga lainnya perannya masih perlu pembuktian lanjutan karena tidak semua serangga pengunjung bunga berperan sebagai penyerbuk.

Hasil penelitian juga memberikan arah bagi pemulia tanaman (breeder) agar tidak hanya memahami besarnya nilai outcrossing tetapi juga harus mengkaji besarnya nilai selfing yang terjadi di populasi uji keturunan. Hasil penelitian perkawinan silang $T$. sinensis memiliki implikasi strategis yang penting dalam pengelolaan plot uji keturunan yang telah dibangun untuk menjadi basis genetik dalam pembangunan populasi perbanyakan.

Rekomendasi dari penelitian ini dapat digunakan untuk mendukung kelayakan plot uji keturunan apabila akan dikonversi menjadi kebun benih semai, karena populasi $T$. sinensis pada uji keturunan memiliki sifat outcrossing tinggi, sehingga memungkinkan untuk tetap mempertahankan diversitas genetiknya. Pengelolaan sumber benih harus mempertimbangkan kondisi tersebut dengan menghindari adanya campuran famili-famili dalam populasi yang berkerabat. Potensi munculnya perkawinan campuran dalam populasi $T$. sinensis menuntut adanya alternatif perbaikan dalam penyusunan strategi program pemuliaan spesies $T$. sinensis di tahap lanjut. Peluang penggunaan skema pemuliaan yang melibatkan populasi dengan banyak famili di dalamnya akan memberikan peluang yang lebih besar bagi setiap individu untuk melakukan rekombinasi genetik melalui perkawinan silang acak dengan harapan mampu menghasilkan kemajuan genetik berkelanjutan, dengan asumsi selama ukuran populasi efektif yang cukup besar mampu dipertahankan.

\section{KESIMPULAN DAN SARAN}

\section{A. Kesimpulan}

1. Sistem perkawinan $T$. sinensis di hutan rakyat mempunyai kecenderungan kawin silang yang ditunjukkan oleh nilai outcroosing yang tinggi ( $\mathrm{tm}=93,8 \%$ ), peluang terjadinya perkawinan inbreeding dan selfing yang rendah yaitu masing-masing (tm-ts $=17,2 \%)$ dan nilai selfing $(s=6,1 \%)$.

2. Diversitas genetik populasi surian ( $T$. sinensis) yang saat ini sudah ditanam di plot uji keturunan diprediksi masih mampu dipertahankan sehingga konversi 
plot uji keturunan $T$. sinensis menjadi kebun benih semai yang mengandalkan perkawinan terbuka relatif masih aman untuk diteruskan karena populasi di uji keturunan masih mampu menjaga diversitas genetiknya.

\section{B. Saran}

Untuk lebih mengoptimalkan plot uji keturunan dapat disarankan agar mengkaji seberapa besar pohon berbunga serempak dan bagaimana pola aliran gen dalam plot uji keturunan.

\section{DAFTAR PUSTAKA}

Agnes Doligez, \& Joly, H. I. (1997). Mating system of Carapa procera (Meliaceae) in the French Guiana tropical forest. American Journal of Botany, 84(4), 461-470. https://doi.org/10.2307/ 2446022

Azizah, \& Siregar, I. Z. (2011). Keragaman Genetik dan Sistem Perkawinan pada Tegakan Benih Mindi (Melia azedarach Linn.) di Wanayasa, Purwakarta. Institut Pertanian Bogor.

Banu, B., Kurt, B. Y., \& Kaya, N. (2012). Mating system in natural populations of Taurus cedar (Cedrus libani A.Rich.). Turk J Agric For, 36, 379-387. https://doi.org/10.3906/tar-1104-29

Bawa, K. . (1990). Plant pollinator interaction in tropical rain forests. Ann. Rev. Ecol. Syst., 21(1), 399-422. Retrieved from https://www.annualreviews.org/doi/abs/ 10.1146/annurev.es.21.110190.002151? journalCode=ecolsys. 1

Brown, A. (1989). Genetic characterization of plant mating systems. In A. K. and B. W. AHD Brown, MT Clegg (Ed.), 'Plant Population Genetics, Breeding and Genetic Resources (pp. 145-162). Sunderland: Sinauer Associates.

Chiari, L., Resende, R.M.S., \& Matinda, E. (2010). Mating System Parameters in Stylosanthes guinensis (Aubl.) CW. Based on RAPD Markers. African Journal of Biotechnology, 9(36), 58205822.

Clegg, MT. 1980. Measuring plant mating systems. Bioscience 30: 814-818

de Campos, T., da Cunha' M.O, de Sousa' A.D.B., R Teixeira' R.B, Raposo, A., Sebbenn, A.M \& Wadt, L.H. 2013. Mating system parameters in a high density population of andirobas in the Amazon forest. Pesq. agropec. bras. vol.48 no.5 Brasília May 2013.

Dvorak, W., Hamrick, J., Furman, B., Hodge, G., \& P, J. (2002). Conservation strategies for Pinus maximinoi based on provenance, RAPD and allozyme informationNo Title. Forest Genetic, 9(4), 263-274.

Edmond, J.M. \& staniforth, M. (1998). Toona sinensis. Meliaceae. Curtis Botanical Magazine. 15, 186-193.

Feres, J. M. A., Sebbenn, M., Guidugli, C., Mestriner, M. A., Moraes, M. L. T., \& Marin, A. (2012). Mating system parameters at hierarchical levels of fruits, individuals and populations in the Brazilian insect - pollinated tropical tree, Tabebuia roseo-alba (Bignoniaceae) No Title. Conservation Genetics, 13(2), 393-405.

Ferreira T. G. T., H. A. Penha, M. I. Zucchi, A. A. Santos, L. R. Hanai, N. Junqueira, M. F. Braga, R. Vencovsky \& M. L. C. Vieira. 2009. Outcrossing Rate In Sweet Passion Fruit Based On Molecular 
Markers. Plant Breeding doi:10.1111/j.1439-0523.2009.01744

Ferreira, M. A. J. d., Vencovsky, R., Vieira, M. L. C., \& Queiróz, M. A. de. (2000). Outcrossing Rate and Implications for The Improvement of a Segregating Population of Watermelon. Acta Horticulturae $\quad 510, \quad 47-54$. https://doi.org/10.17660/Acta

Hortic.2000.510.7

Finkeldey, R., \& Hattemer, H. (2007). Tropical Forest Genetics. Berlin: Springer.

Finkeldey R. 2005. Pengantar Genetika Hutan. Terjemahan oleh Edje Djamhuri, Iskandar Z. Siregar, Ulfah. J. SiregardanArti W. Kertadikara. ASEAN-EU University Network Programme (AUNP). Fakultas Kehutanan IPB. Bogor

Frankham, R., Ballou, J.D., \& Briscoe, D. A. (2002). Introduction to conservation genetics. Cambridge UK: Cambridge University Press.

Freitas1, M.L.M, Sebbenn, A.M, Moraes, M.L.T \& Lemos, E. G. (2004). Mating system of a population of Myracrodruon urundeuva F.F. \& M.F. Allemão using the AFLP molecular marker. Gen. Molecular Biology, 27(3), 425-431.

Fuchs, E.J \& Hamrick, J. . (2011). Mating system and pollen flow between remnant populations of the endangered tropical tree, Guaiacum sanctum (Zygophyllaceae). Conserv Genet, 12, 175-185.

Gaiotto FA, Bramucci, M. \& Grattapaglia, D. (1997). Estimation of outcrossing rate in a breeding populations of Eucalyptus urophylla with dominant RAPD and
AFLP markers. In IUFRO - Conference on Silviculture and Improvement of Eucalyptus (p. 2:53-57.). Salvador: IUFRO.

Han, Y.C, Teng C.Z, Gituru R.W, MingQ.Z, Zhong L. H \& Yun C.S. 2009. Mating system and genetic diversity in natural populations of Nelumbonucifera (Nelumbonaceae) detected by ISSR markers. Plant Systematics and Evolution. January 2009, Volume 277, Issue 1-2, pp 13-20.

Hong, C. N., Lee, S., Kit-Siong, K. N., Muhammad, N., \& Ratnam, W. (2009). Mating system and seed variation of Acacia hybrid (A. mangium $\times$ A. auriculiformis). Journal of Genetics, 88(1).

Iddrisu, N. A, \& Ritland, K. (2004). Genetic variation, population structure, and mating system in bigleaf maple (Acermacrophyllum Pursh). Can. J. Bot, 82, 1817-1825.

Jones, J.M \& Gibson, J. P. (2012). Mating System Analysis of Alnus maritime (Seaside Alder), a Rare Riparian Tree. Castanea, 77(1), 11-20.

Kundu, S.K. 1999. The mating system and genetic significance of polycarpy in the neem tree (Azadirachtaindica). Theoretical and Applied Genetics November 1999, Volume 99, Issue 7-8, pp 1216-1220

Lee, C. T, Lee, S. L, Ng, K. K. S, Faridah2, F.S, Siraj, S.S. \& Norwati, M. (2011). Estimation Of Outcrossing Rates In Koompassia Malaccensis From An Open-Pollinated Population In Peninsular Malaysia Using Microsatellite Markers. Journal of 
Tropical Forest Science, 23(4), 410416.

Lee, S.L., Wickneswari, R., Mahani, M.C., \& Zakri, A. H. (2000). Mating system parameters in a tropical tree species, Shorea leprosula Miq. (Dipterocarpaceae), from Malaysian lowland dipterocarp forest. Biotropica, $32,693-702$.

Lee, S. L. (2000). Mating system parameters of Dryobalanops aromatica Gaertn. f. (Dipterocarpaceae) in three different forest types and a seed orchard. Heredity, 85, 338-345.

Lemes, M.R., Grattapaglia, D., Grogan, J., Proctor, J. \& Gribel, R. (2007). Flexible mating system in a logged population of Swietenia macrophylla King (Meliaceae): implications for the management of a threatened neotropical tree species. Plant Ecol, 192, 169-179.

Liengsiri, C., Yeh, F.C, \& Boyle, T. J. B. (1998). Isozyme analysis of tropical forest tree, Pterocarpus microcarpus Kurz. In Thailand. For. Ecol. Manage., 74, 13-22.

Middleton, D. J. (2007). Flora Malesiana Series 1. Seed Plant Volume 18. Apocynaceae (subfamilies Raouvolfioi deae and Apocoynoideae). sinne locco: Foundation Flora Malesiana. National Herbarium Netherland.

Muchugi, A. Muluvi, G.M., Simon, A.J, Wachira, F.N \& Jamnadass, R. H. (2008). Estimates of out crossing rates in natural breeding population of Warburgia ugandensis using Amplified Fragment Length Polymorphism (AFLP). African Journal of Biotechnology, 7(2), 139-146.
Muluvi, G.M., Sprent, J.I., Odee, D., \& Powell, W. (2004). Estimates of out crossing rates in Moringa oleifera Amplified Fragment Length Polymorphism (AFLP). African Journal of Biotechnology, 3(2), 146-151.

Muoki, R.C ,F. Wachira, F.N, Pathak, R.S. \& Kamunya, S.M. . 2007. Assessment of the mating system of Camellia sinensis in biclonal seed orchards based on PCR markers. The Journal of Horticultural Science and Biotechnology. Volume 82, 2007 - Issue 5.

Murni, P., Syamsuardi, Nurainas, Mansyah, E. \& Chairul. 2016. Genetic Variability and Out-crossing rate in open pollinated Duku 'Kumpe' (Lansium parasiticum (osbeck) K.C. Sahni \& Bennet.), a Potential Type of Duku from Jambi, Indonesia.Der Pharmacia Lettre, 2016, 8 (18):185-191

Nurjahjaningsih, I. L. G. (2010). Sistem perkawinan di kebun benih Pinus merkusii di Jember. In Prosiding Ekspose Hasil-Hasil Penelitian Balai Besar Penelitian Bioteknologi dan Pemuliaan Tanaman Hutan. Jogjakarta.

Pramono, A.A, Palupi E.R, Siregar, I. Z \& Kusmana, C. 2016. Bunga Surian (Toona sinensis (A. Juss.) M. Roem.): Morfologi, Fenologi, dan Serangga Pengunjung. Jurnal Perbenihan Tanaman Hutan Vol.4 No.2, Desember 2016: 67-80p-ISSN : 2354-8568e-ISSN : 2527-6565.

Rao, H., Patterson, B., Potts, B., \& R Vaillancourt. (2008). A microsatellite study on out-crossing rates and contamination in an Eucalyptus globulus breeding arboretum. Journal 
Forest. Restoration, 19(2), 136-140.

Ritland K. (1983). Estimaton of Mating System. In S. Tanksley \& T. Orton (Eds.), Isozymes in Plant Genetic and Breeding (pp. 289-302). Amsterdam: Part A Elsevier Science`Publishers.

Ritland K. (1990). A Series of FORTAN Computer Programs for Estimating Plant Mating System. Journal of Heredity, 81, 235-237.

Ritland K. (2002). Extensions of models for the estimation of mating systems using $\mathrm{n}$ independent loci. Heredity, 88, 221228.

https://doi.org/10.1038/sj.hdy.6800029

Sambrook, J., Fritsch, E. F., \& Maniatis, T. (1989). Molecular Cloning. In $A$ laboratory manual. s.1: Cold Spring Harbor Laboratory Press.

Sánchez L. G. H. 2008. Genetic diversity and mating system analysis of Cedrelaodorata L. (Meliaceae) populations under differ Magister Scientiae en Manejoy Conservación de Bosques Naturales Biodiversidadent human dominated landscapes and primary forests. Turrialba, Costa Rica, $74 \mathrm{p}$.
Shiraishi, S. \& Watanabe, A. 1995. Identificatuion of chloroplat genome between Pinus densiflora Sieb.et.Zucc and P. Thunbergii Parl. Base on the polymorphism in rbeL Gene. Journal of Japan Forest Society 77:429-4326.

Stauffer, A., \& Adam, W. . (1993). Allozyme Variation and Mating System of Three Dauglas-fir Stand in Switzerland. Silvae Genetica, 42, 4-5.

Vogler, D., \& Kalisz, S. (2001). Sex among the flowers: the distribution of plant mating systems. Evolution, 55, 202204.

Wadt, L., \& Kageyama, P. (2004). Structur Genetic System Piper hispidinervum. Pesq. Agropec. Brazil, 3939(2), 151-15.

Wahyudiningsih, T. S. (2015). Program Pemuliaan Jelutung Rawa (Dyera lowii Hook.f.) di Kalimantan Tengah. Universitas Gadjah Mada.

Wright S. (1965). The interpretation of population structure by F-statistics with special regard to systems of mating. Evolution, 19, 395-420. 